\title{
Experimental analyses of the commensal relation between intertidal gastropods Patelloida mufria and the trochid Austrocochlea constricta
}

\author{
B. D. Mapstone, A. J. Underwood* and R. G. Creese** \\ School of Biological Sciences, Department of Zoology, University of Sydney, Sydney, N. S. W. 2006, Australia
}

\begin{abstract}
Intertidal acmaeid limpets Patelloida mufria are found almost exclusively on the shells of other gastropods, although sub-tidal limpets are found on rock. The limpets are more abundant on the trochid Austrocochlea constricta than on other species; this preference is not explained by the relative area of shells of $A$. constricta. A. constricta, and the next most common host, the turbinid Subninella undulata, were found primarily in pools during low tide; $P$. mufria were relatively more abundant on hosts in pools than those out of pools. When displaced from their hosts, $P$. mufria rapidly climb onto other gastropods, preferring $A$. constricta over other species. Limpets often changed hosts, but usually moved onto an $A$. constricta rather than other species. In the field, limpets tended to move off $A$. constricta that were moving out of pools. Most limpets were found on and under the basal body-whorl of the host's shell; this pattern was maintained by movements of limpets transplanted to the apex of the host's shell, and many transplanted limpets moved towards the lower end of the shell even when the host was turned upside down. The result of this pattern of distribution of limpets and their hosts, and the position of limpets on their hosts was to increase the probability that $P$. mufria would be in pools during low tide. Choice of a host was influenced by experimental attempts to remove microalgae from the shell; treated shells were not usually less attractive to limpets. Less artificial experiments revealed that $P$. mufria chose individual $A$. constricta in inverse proportion to the hosts' recent contact with limpets. Hosts previously ungrazed by limpets were more attractive to $P$. mufria. These results suggested influences of food supply, or the previous presence of other limpets, on the choice of host. Field experiments demonstrated great susceptibility of $P$. mufria to desiccation during low tide. Both intertidal and sub-tidal morphs of $P$. mufria survived much better in pools, or, when out of a pool, on the shell of an A. constricta. Clearly, an important factor in the distribution of the limpets was the rapid mortality of limpets when emersed without a host. Another source of mortality was predation by the whelk Morula marginalba, which readily consumed adult limpets when these were on the rock in pools. This mortality was reduced, virtually to zero, when the limpets were on a host's shell, probably because of behaviour of $A$. constricta. The extremely limited distribution of intertidal $P$. mufria can be explained by a set of behavioural responses to find a host rapidly when dislodged from one, and the behaviour of suitable hosts staying in pools during low tide. The advantages of being on a host include increased probability of being submersed during low tide, and reduced chances of being eaten by predatory whelks. The lack of small limpets from the surfaces of rock in pools is not readily explained, but may involve choices of substratum during settlement. The great advantages gained by limpets when on their hosts are largely brought about by behavioural patterns of the host, not the limpets.
\end{abstract}

\section{INTRODUCTION}

During the past 2 decades there has been considerable investigation of the factors influencing the distribution and abundance of intertidal limpets (Frank,

\footnotetext{
- Addressee for reprints and correspondence

- Current address: University of Auckland Marine Laboratory, RD Leigh, Northland, New Zealand
}

1965; Sutherland, 1970; Stimson, 1973; Branch, 1975a; Choat, 1977; Underwood, 1978; Creese, 1980, 1982; Creese and Underwood, 1982). Limpets occur in a variety of intertidal habitats and exhibit a great diversity of habits, ranging from habitat generalists through varying degrees of specialization to extreme, even obligate, habitat specialists (Choat and Black, 1979). The potentially limiting biological and physical factors 
with which habitat generalists must contend are largely extrinsically determined - by apparently stochastic processes of larval settlement and the status quo of the community at the time and place of settlement. Conversely, the characteristic ecological and behavioural specializations of habitat specialists are presumed to ameliorate the biological and physical stresses normally suffered by less specialized species. Branch (1976) and Choat and Black (1979) have argued that the reduction of biological stresses, such as predation and inter-specific competition for space and food, have been the major selective agents responsible for the evolution of specialized habits by limpets. It is, however, difficult to test such hypotheses.

Specialization by limpets takes a number of forms. One form is demonstrated by such behaviours as homing to particular sites (Frank, 1964; Sutherland, 1970; Mackay and Underwood, 1977) or territorial behaviour in defence of a home range. Stimson $(1970,1973)$ demonstrated, by manipulative field experiments, that territorial behaviour by the owl limpet Lottia gigantea reduced the intensity of exploitative competition from smaller acmaeid limpets and other grazers. Branch (1975a, b, 1976) has suggested that the territorial behaviour of 2 species of South African limpets (Patella cochlear and $P$. longicosta) also reduced the intensity of competition for food between those and other species.

A second form of habitat specialization is shown by intertidal limpets that settle as planktonic larvae only in particular regions of the shore. For example, in New South Wales, Notoacmaea petterdi apparently settles only on vertical rock surfaces in the high intertidal regions of rocky shores (Creese, 1980). Branch (1976) suggested that larval $P$. cochlear settled preferentially on the shells of conspecific adults. Such behaviour is claimed to be widespread among other intertidal organisms (e.g. Barnes, 1953; Knight-Jones, 1953; Meadows and Campbell, 1972; Crisp, 1974) but in many studies of limpets no evidence has been presented to distinguish between preferential settlement by larvae and differential survival after random settlement (Underwood, 1979).

Several other species of limpets have specific associations with other organisms. Creese (1982) divided these limpets into 2 groups: those which are associated with seagrasses or kelps (Test, A., 1945; Graham and Fretter, 1947; Vahl, 1971; Branch, 1975b; Black, 1976; Choat and Black, 1979) and those that live in associations with other animals. Among the latter is Patelloida latistrigata found almost exclusively amongst barnacles (Creese, 1982). Another association involves Acmaea testudinalis apparently found in greatest abundance on, and recruits specifically to, an encrusting coralline alga (Steneck, 1982).
Among the most specialized of all habitats chosen by limpets are the shells of other species. This is a common hard substratum in sublittoral soft sediments and is the major habitat for many mesogastropod limpets such as the genera Crepidula (Orton, 1950; Hendler and Franz, 1971), Capulus (Thorson, 1965) and Calyptraea (Wyatt, 1960). The archaeogastropod Patelloida lampanicola is also found primarily on the shells of the snail Batillaria zonalis in Hong Kong Bay (Morton, 1980). Despite the prevalence of living on host shells in muddy areas, this form of habitat specialization is very remarkable for limpets on rocky shores.

Acmaea asmi, a much-cited limpet, lives exclusively on shells of other gastropods, particularly Tegula funebralis (A. R. Test, 1945; Eikenberry and Wickizer, 1964; Alleman, 1968). F. H. Test (1945) and Eikenberry and Wickizer (1964) suggested that by residing on the lower whorls of $T$. funebralis, A. asmi alleviated the effects of 'desiccation, direct sunlight, predation, and wind and wave action'. The limpets apparently selected their hosts by chemosensory detection, although Alleman (1968) suggested that tactile selection through tentacular contact was also involved. In New South Wales, Creese (1978) and Ponder and Creese (1980) noted that Patelloida mimula was restricted to the shells of the oyster Saccostrea commercialis in estuarine habitats and $P$. mufria (Lamarck) was restricted to the shells of other gastropods, particularly the trochid snail Austrocochlea constricta (Lamarck), on sheltered intertidal rocky shores (although apparently the latter species of limpet occurred only on the substratum in sub-tidal habitats).

In few of the above examples have the factors determining the restricted distribution of the limpets, or the consequences of habitat specialization been rigorously examined. The present study was therefore undertaken in an attempt to determine the processes involved in, and the consequences of, the choice of such a specialized habitat by Patelloida mufria. In this study, the local distribution and abundance of intertidal $P$. mufria was examined on a number of rocky shores around Sydney (N. S. W., Australia), to determine the degree to which the limpet was confined to the shells of other intertidal gastropods. After regular sampling of local populations, several hypotheses were proposed for the maintenance of the association between $P$. mufria and its hosts. The major hypotheses concerned reduction, when on a host, of physiological stress of the limpets due to physical factors such as direct sunlight, wind and wave energy, and the role of the host in avoidance of predation. In addition, we hypothesized that the choice of a host snail would be influenced by the availability of food on its shell. In this paper we describe laboratory and field experiments designed to test these hypotheses. 


\section{MATERIALS AND METHODS}

\section{Study sites}

Field work was done on 5 sandstone rock platforms around Sydney $\left(151^{\circ} \mathrm{E}, 34^{\circ} \mathrm{S}\right.$ ): Jibbon Reef (south of Sydney); in the Cape Banks Scientific Marine Research Area; Fairy Bower and Mona Vale (in the northern suburbs of Sydney); and Green Point (north of Sydney; Underwood, 1981). The aspects of the sites ranged from north to south-west and all were relatively low wave-energy coastal shores with little or no estuarine influence. Patelloida mufria and its principal hosts were uncommon at exposed locations. The study spanned the period 1975-1983.

Patelloida mufria is a south-temperate species distributed around the southern coasts of Australia from Geraldton on the west coast to northern New South Wales in the east (Ponder and Creese, 1980). Intertidal $P$. mufria are small, rarely reaching more than $10 \mathrm{~mm}$ shell length, and most individuals are found on the shells of other gastropods. Few survive longer than $1 \mathrm{yr}$ from settlement, which occurs between May and September; the greatest mortality occurs during summer (Creese, 1978). In sub-tidal populations, $P$. mufria live on rocky substrata, often in great densities, and individuals can grow to much larger sizes than are found intertidally (Fletcher, pers. comm.). Ponder and Creese (1980) assumed that sub-tidal limpets were conspecific with intertidal P. mufria. A recent, more extensive examination of sub-tidal material has revealed the possibility that the sub-tidal limpets, while closely resembling the intertidal ones in terms of general shell characteristics, may have a slightly different radula (Creese, unpubl.). The true identity of the sub-tidal limpet will have to await a more detailed examination.

\section{Sampling Patelloida mufria and its hosts in the field}

The distribution and abundance of Patelloida mufria and other gastropods were sampled in several hundred randomly distributed 0.25 or $1.0 \mathrm{~m}^{2}$ quadrats on different shores throughout the study period. The following data were collected: (1) Percent cover of permanent pools at low tide, measured on a 100 point grid in each quadrat. (2) Abundance of host gastropods (snails Austrocochlea constricta, Bembicium nanum [Lamarck], Nerita atramentosa Reeve, Subninella undulata [Solander]; limpet Cellana tramoserica [Sowerby]; whelk, Morula marginalba Blainville) in and out of pools. (3) Abundance of $P$. mufria on the substratum and on the shells of each host species, in and out of pools, and the position (i.e. near the base or apex) of each $P$. mufria on its host's shell. In addition, at least
100 of each host species were collected randomly from pools and emersed rock during low tide, and their sizes (maximum basal shell diameter measured with vernier callipers) and the numbers and sizes of $P$. mufria they carried were recorded.

\section{Estimation of suriace areas of host shells}

To determine the relative areas of potentially habitable surface for Patelloida mufria represented by its most favoured host gastropods, 10 randomly chosen, weighed individuals of each species were inverted and immersed up to the aperture of their shells in oil of low viscosity. The shells were then allowed to drain for 2 min and reweighed. Assuming equal rates of absorption and retention of oil by all shells, the surface area of each shell was proportional to the weight of oil required to cover it. For each species, the net weight of oil was regressed on shell-length and shell-length squared to estimate the relative surface areas of average individuals carrying one or more $P$. mufria. The smallest host species (Morula marginalba) was assigned an area of one arbitrary unit; relative areas of the other species were then indexed to that species. The index of area of an individual of mean size for each species was then multiplied by the mean abundance of that species at any site to estimate the total potentially habitable area it represented for $P$. mufria. These estimates were used to assess whether the observed differential distribution of $P$. mufria among hosts could be explained simply by the relative surface areas of the shells of different host species.

\section{Treatment of animals in field experiments}

Field experiments involved caging, marking, relocation and immobilization of gastropods. Stainless-steel cages $\left(1\right.$ mesh $\left.\mathrm{cm}^{-1}\right)$ of 2 sizes $(15 \times 15 \times 5 \mathrm{~cm} ; 20 \times$ $20 \times 5 \mathrm{~cm})$ were used to constrain gastropods. Cages were fastened to the substratum with stainless-steel screws screwed into plastic rawl-plugs in the sandstone.

When not in cages, the gastropods used in field experiments were, in general, free-moving, and marked, when necessary, with small dots of fast drying, non-toxic marine paint. In 2 experiments, however, hosts were fastened to the substratum. In the first, empty shells of Austrocochlea constricta were secured to the substratum by glueing them to short lengths of 8 gauge galvanized wire stuck into rawl-plugs in the substratum. Shells were secured in place 2 to $4 \mathrm{~d}$ prior to the start of an experiment to emulate the shells of stationary, live $A$. constricta. In the second instance, 
living $A$. constricta were glued to the substratum, without wire supports, in upright or inverted positions.

When Patelloida Inufria were removed from their original hosts and placed either on a new host or on the substratum, they were kept wet for at least $30 \mathrm{~min}$ after being disturbed before the experiments began. This ensured that the limpets had attached in the new situation. Extreme care was taken when handling $P$. mufria to ensure that their shell margins, which were often thin and fragile, were not damaged. Damaged individuals were discarded. Results of many experiments relied on determining whether Patelloida mufria were alive or dead after treatment. Where this was not obvious, limpets were inverted in shallow pools and observed for $15 \mathrm{~min}$. If no movement of the foot, head or tentacles was apparent during that time, they were assumed to be dead.

\section{Maintenance and manipulation of gastropods in the laboratory}

Most laboratory experiments were of short duration (less than $3 \mathrm{~d}$ ) and involved animals collected from the field on the day prior to the experiment. In the laboratory, gastropods were kept in 21 plastic containers or small (10 l) glass aquaria. Seawater was supplied from a recirculating system within the laboratory and all containers were aerated. Some experiments were done with $6 \mathrm{~h}$ tidal simulations, simply by draining or filling the containers at appropriate intervals. All other experiments were done under simulated high tide conditions. When gastropods were immobilized, or when empty shells were used, the apertures of the shells were plugged with plasticene. This effectively immobilized living gastropods, and denied Patelloida mufria access to the insides of empty shells.

To examine the effect of food on the selection of hosts by Patelloida mufria, it was necessary to remove epizoic algae from hosts' shells in several treatments and to promote algal growth on shells in others. Algae were removed from shells in 3 ways: (1) shells were kept in darkness for $4 d_{\text {; }}$ (2) shells were scrubbed with concentrated sulphuric acid and then washed with distilled water and seawater; (3) shells were immersed for $7 \mathrm{~min}$ in, sequentially, an extremely hypersaline $(\mathrm{NaCl})$ solution, seawater, distilled water, and seawater again. Fluorescence microscopy was used to note the presence or absence of chlorophyll on the shells before and after treatment. In the latter 2 methods, care was taken to avoid damage of the snails inside the shells. Algal growth was enhanced by constant illumination for four days prior to the experiments.

Death of Patelloida mufria was assessed in the laboratory as it was in the field. In experiments on predation, empty $P$. mufria shells were assumed to be the remains of limpets that had been eaten; these were recorded separately from those limpets which were dead but intact.

\section{RESULTS}

\section{Intertidal distribution of Patelloida mufria}

Patelloida mufria were found in mid-littoral regions, generally on horizontal surfaces, above the upper limits of macro-algal beds (Underwood, 1981) mostly in areas dominated by gastropods (Underwood et al., 1983). At all locations, they were very rarely found on the substratum $(<0.001$ of all limpets), but were far more abundant on the shells of $A$. constricta than on shells of other gastropods (Fig. 1). The limpets were also more abundant on the shells of gastropods in pools than on hosts that were out of pools during low tide (Table 1). $23.7 \%$ of hosts with $P$. mufria had more than one limpet; almost all of the multiple limpets were juveniles.

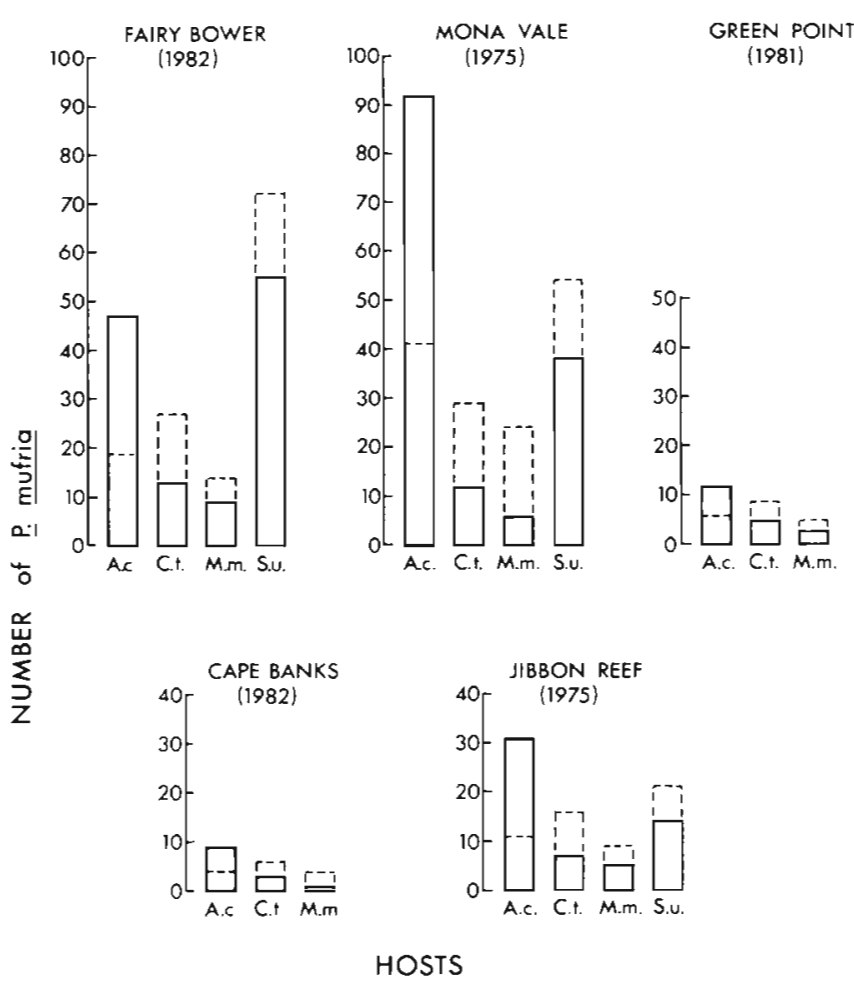

Fig. 1. Patelloida mufria. Numbers per 100 animals of different hosts sampled at 5 localities around Sydney (A. c. = Austrocochlea constricta; C. t. = Cellana tramoserica; $\mathrm{M}$. m. = Morula marginalba; S. u. = Subninella undulata). Dashed lines: expected numbers on each host, in each sample, if $P$. mufria were distributed at random according to the relative areas of hosts' shells 
Table 1. Patelloida mufria. Distribution on Austrocochlea constricta and other hosts collected from pools and dry rock during low tide

\begin{tabular}{|c|c|c|c|c|c|c|}
\hline & \multicolumn{2}{|c|}{ Pools } & \multicolumn{2}{|c|}{ Emersed } & \multirow[b]{2}{*}{$\begin{array}{c}\text { Chi- } \\
\text { squared }\end{array}$} & \multirow[b]{2}{*}{$P$} \\
\hline & $\begin{array}{c}\text { No. } \\
\text { sampled }\end{array}$ & $\begin{array}{l}\text { No. with } \\
P . \text { mufria }\end{array}$ & $\begin{array}{c}\text { No. } \\
\text { sampled }\end{array}$ & $\begin{array}{l}\text { No. with } \\
\text { P. mufria }\end{array}$ & & \\
\hline \multicolumn{7}{|l|}{ Cape Banks } \\
\hline A. constricta & 100 & 13 & 100 & 0 & 13.9 & $<0.001$ \\
\hline Other hosts & 400 & 10 & 400 & 0 & 10.1 & $<0.005$ \\
\hline \multicolumn{7}{|l|}{ Fairy Bower } \\
\hline A. constricta & 100 & 55 & 100 & 41 & 3.9 & $<0.05$ \\
\hline Other hosts & 400 & 90 & 300 & 13 & 45.1 & $<0.001$ \\
\hline
\end{tabular}

The skew in the distribution of Patelloida mufria on potential hosts, apparently favouring Austrocochlea constricta, was not explained by the relative abundances of the host species nor by differences in the total relative surface areas of their shells (Fig. 1). $P$. mufria occurred more frequently on $A$. constricta and less frequently on most other hosts than expected under either of these models. A. constricta was thus considered to be the most important host of $P$. mufria. Juvenile $P$. mufria were restricted, almost exclusively, to the shells of $A$. constricta, Subninella undulata and Morula marginalba, less than $0.1 \%$ of all juveniles being found on hosts of other species. Adult limpets occurred on all hosts except $M$. marginalba, and there was generally no correlation between size of limpet and size of host (for samples from 10 areas: $P>0.10$ in 6 samples of 55 to 100 pairs; $P>0.40$ in 3 samples with 150 to 250 pairs; and $P<0.05$ for 1 sample of 55 pairs). The proportion of limpets found basally on their hosts was, however, considerably greater than the proportion found apically ( $\chi^{2}$ Tests, $P<0.001$ in all of 5 samples of 200 to 300 limpet-host pairs). Although large $P$. mufria were rarely found on small hosts, small
$P$. mufria occurred on hosts of all sizes. $P$. mufria of all sizes were uncommon on juvenile hosts.

\section{Distributions of host species}

Following the methods of Underwood (1976), the distribution of adults of each host species was determined with respect to permanent pools and emersed areas at low tide. Austrocochlea constricta and Subninella undulata showed positive preferences for pools at low tide whilst Bembicium nanum, Cellana tramoserica and Morula marginalba were either randomly distributed with respect to pools or preferred non-pool areas (Table 2). These results were consistent with Underwood's (1976) findings for $A$. constricta, but differed for $C$. tramoserica and $B$. nanum. The causes of such differences are unknown, but large differences in the cover of pools in the area sampled here compared with those areas analysed in the earlier paper might be important (Underwood, 1976). The previous study also demonstrated that Nerita atramentosa, which was not examined here, showed no preference for pools.

Table 2. Distribution of adult host gastropods during low tide (analysed by the regression of proportion of gastropods in quadrats on the proportional area of pools in those quadrats; see Underwood, 1976)

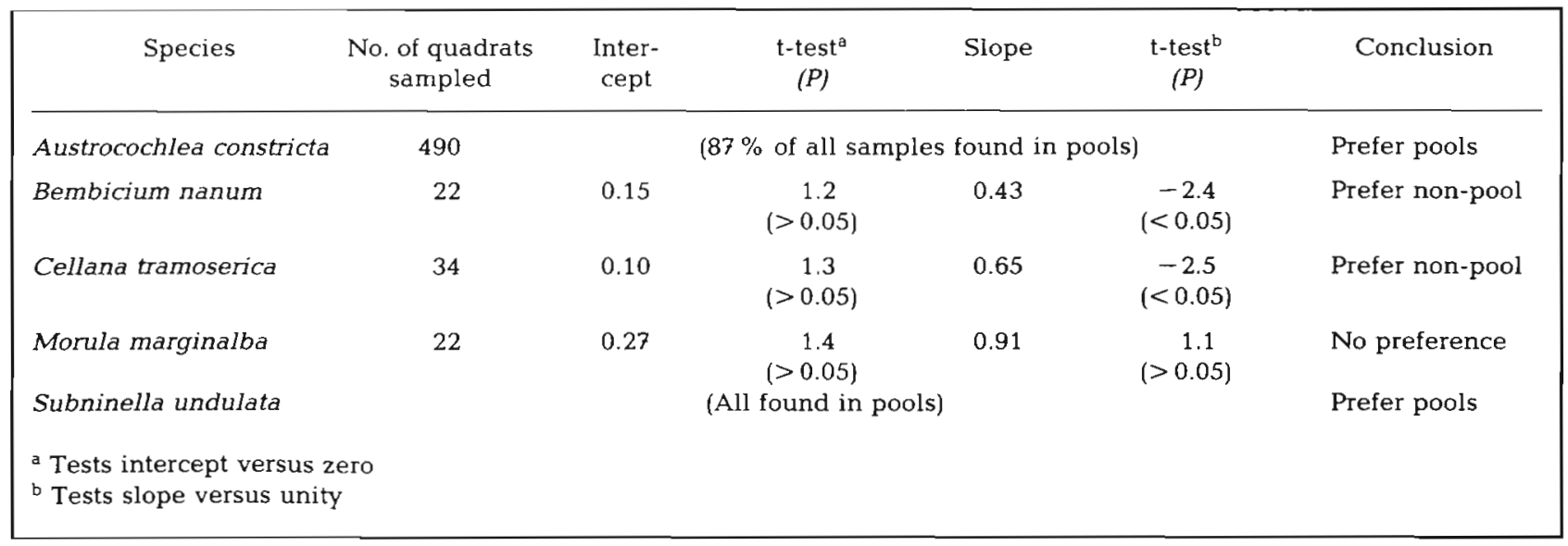




\section{Maintenance of the observed distribution of Patelloida mufria}

\section{Settlement of Patelloida mufria}

During sampling of local populations, intensive searches for newly-recruited Patelloida mufria ( $<2 \mathrm{~mm}$ shell length) were made in emersed areas, shallow pools, deep pools, and on the shells of other gastropods. Newly recruited $P$. mufria were extremely rare on the substratum, whether in emersed areas, shallow pools or deep pools $1<0.01 \%$ of all juveniles seen). Thus, $P$. mufria either settle preferentially on the shells of other gastropods, or they settle randomly and those that settle on the substratum die very quickly, or very rapidly move onto the shell of another gastropod.

\section{Selection of hosts by juvenile and adult Patelloida mufria}

When intertidal Patelloida mufria were removed from their hosts and placed on the substratum in pools, they moved rapidly around until they encountered another gastropod, even another $P$. mufria, and then moved onto its shell. This behaviour was not observed in limpets collected subtidally or displaced from one host to another. At Jibbon Reef, groups of 10 P. mufria were placed on the substraturn in cages with 10 Austrocochlea constricta and 10 individuals of an alternate host species. Four alternate hosts were tested: Bembicium nanum, Cellana tramoserica, Nerita atramentosa, and Subninella undulata. The distribution of $P$. mufria among hosts was recorded after $3 \mathrm{~d}$.

When given a choice of any of the 4 alternative hosts, significantly more limpets moved onto Austrocochlea constricta than expected if selection of a host was the result of random movement (Fig. 2). Observations of the movements of Patelloida mufria during similar experiments in the laboratory indicated that, in general, the limpets moved onto the first curved shell encountered, but if 2 or more shells were encountered in close proximity and 1 was an $A$. constricta, $A$. constricta was always chosen over other species. Once on a host shell, $P$. mufria frequently changed hosts when 2 or more hosts came into contact, moving directly from one host to another without moving onto the substratum. During these changes, $P$. mufria would not move from an $A$. constricta to a less preferred species but, if the opportunity arose, would almost always move from a less preferred host onto the shell of an A. constricta. Control treatments showed that small amounts of paint on hosts' shells did not affect selection of hosts by $P$. mufria $\left(\chi^{2}{ }_{2}=0.5, P>0.75\right)$. $P$. mufria showed no preferences for empty shells of any species $\left(\chi^{2}{ }_{3}=0.69, P>0.75\right)$. It was thus considered that the

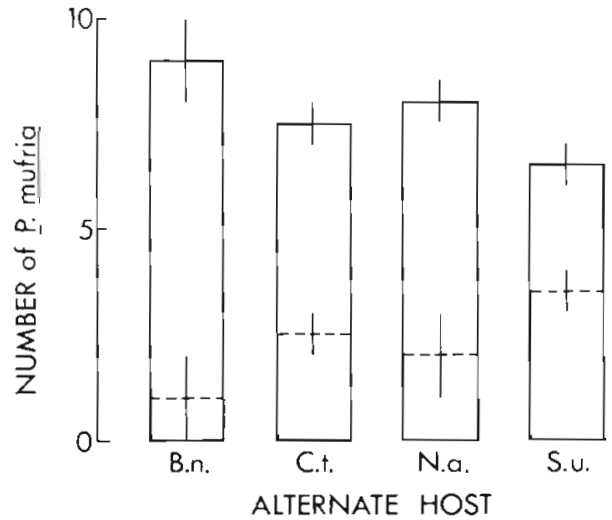

Fig. 2. Patelloida mufria. Mean ( \pm S. E.) numbers climbing onto Austrocochlea constricta from the substratum ( $n=2$ replicate groups of 10 limpets in each experiment). In each trial, $P$. mufria were presented with $10 \mathrm{~A}$. constricta and an equal number of one alternative host (B. $\mathrm{n}$. $=$ Bembicium nanum; C. $t .=$ Cellana tramoserica; N. a. = Nerita atramentosa $_{;}$S. u. = Subninella undulata). Dashed lines: mean numbers ( $\pm \mathrm{S}$. E.) on alternative host in each experiment

relative abundance of $P$. mufria on $A$. constricta resulted, in part at least, from selection among hosts by the limpet.

Movement of Patelloida mufria among individual Austrocochlea constricta

Movement of Patelloida mufria among individual hosts was assessed by observing, in the field, replicate groups of 10 individually marked limpet-host pairs for $4 \mathrm{~d}$. Separate treatments involved juvenile $(<5 \mathrm{~mm})$, sub-adult $(5-7 \mathrm{~mm})$ and adult $(>7 \mathrm{~mm}) P$. mufria, and in all cases the marked snail-limpet pairs were free to move among unmarked Austrocochlea constricta. Limpets of all sizes changed hosts frequently, always moving onto other $A$. constricta in the area. There were no

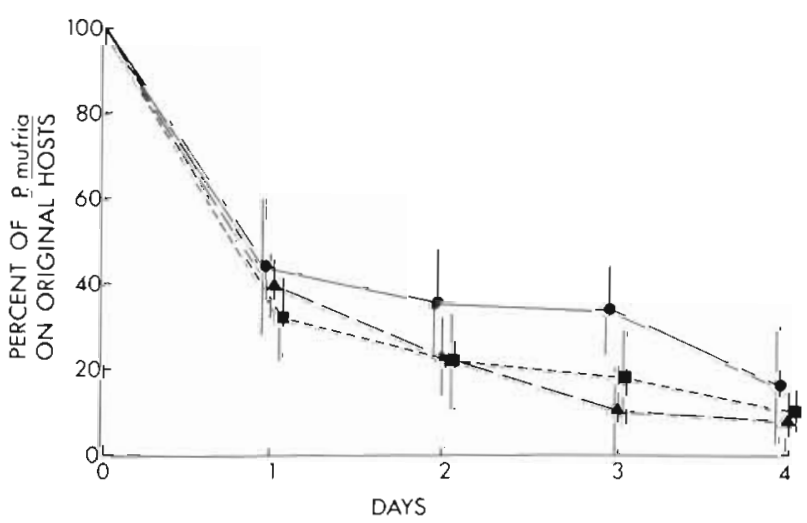

Fig. 3. Patelloida mufria. Mean ( \pm S. E.) percentage of different sizes remaining on their original hosts (Austrocochlea constricta) during $4 \mathrm{~d}$ on a shore at Mona Vale $(n=3$ replicate groups, each of 10 limpets in each size-class). 4 limpets $<5 \mathrm{~mm}$ length; $\square$ to $7 \mathrm{~mm}$ length; $\bullet>7 \mathrm{~mm}$ 
apparent differences in the rates of changing hosts among limpets of different size classes (Fig. 3). Further experiments involved: (1) recording the distribution of replicate groups of $P$. mufria among equal numbers of A. constricta of different shell-banding patterns (Creese and Underwood, 1976); (2) determining whether $P$. mufria changed hosts more frequently when their hosts moved out of pools than when their hosts remained in, or moved into, pools.

The limpets showed no preferences among the 4 different stripe classes of Austrocochlea constricta tested $\left(\chi_{3}^{2}=0.48, P>0.9\right)$. There was, however, a significantly greater tendency for Patelloida mufria to leave a host $A$. constricta that moved out of a pool than hosts that remained in, or moved into pools $\left(\chi^{2}{ }_{1}=\right.$ 10.75, $P<0.005$ ).

\section{Position of Patelloida mufria on host shells}

Manipulative experiments were done to determine whether the large proportion of Patelloida mufria found basally on the shells of Austrocochlea constricta, as described earlier, resulted from positive geotaxis by the limpets or a preference for some characteristic of the basal regions of the shells. In several treatments, groups of $10 \mathrm{P}$. mufria found basally or apically on $A$. constricta were displaced to the opposite ends of their hosts' shells. This was done on the rock platform at Green Point with free-moving $A$. constricta and with snails glued to the substratum in upright or inverted positions. Controls for the possible effects of disturbance of the limpets and/or their hosts, for the experimental displacement of the limpets, and for the presence of glue on the hosts' shells were also done. The positions of $P$. mufria on their hasts were recorded after $24 \mathrm{~h}$.

Results from control treatments showed that experimentally disturbed (but not translocated) limpets did not move around on their hosts' shells more than undisturbed limpets (Fisher's exact test; Table 3). When hosts were free to move, the proportion of experimentally translocated limpets recovered from their original position on the hosts's shell was not significantly different from that of control limpets (Table 3). Thus, limpets that were originally near the apex of a shell tended to remain or return there; limpets originally from the base of a shell tended to remain at or return to the base. When Austrocochlea constricta with basal Patelloida mufria were glued to the substratum in upright or inverted positions, the limpets tended to remain in or return to their original position with respect to the substratum irrespective of their original position with respect to the host shell. Thus, when their host's shell was inverted, limpets originally on the base of $A$. constricta tended to remain near or move toward the substratum, now at the apex of the host's shell. Neither the disturbance of hosts, nor the presence of glue on the shell of a host significantly affected the behaviour of $P$. mufria (Table 4). It was thus concluded that $P$. mufria generally showed positive geotaxis which resulted in the majority of limpets residing near the base of their host's shell. Those few limpets found naturally on the apex of a host's shell tended to return there if displaced.

Availability of food and selection of Austrocochlea constricta by Patelloida mufria

To assess the importance to Patelloida mufria of availability of food on the shells of their hosts, $P$. mufria were allowed access to Austrocochlea constricta from which epizoic algae had been removed, snails which had been kept under constant illumination in an attempt to enhance or, at least, maintain algal growth, and untreated $A$. constricta. In different laboratory experiments, free-moving and immobilized A. constricta, and empty shells were used. The distribution of $P$. mufria among alternate hosts was recorded at intervals of $12 \mathrm{~h}$ for $48 \mathrm{~h}$. Mobile empty shells of $A$. constricta were created by using small

Table 3. Patelloida mufria. Experimental translocation on the shells of Austrocochlea constricta. Data are numbers of limpets recovered after $24 \mathrm{~h}$ on the shore (out of 10 in each treatment); host snails were undisturbed. Fisher's exact tests according to the methods of Ghent (1972)

\begin{tabular}{|c|c|c|c|c|c|}
\hline \multirow[b]{2}{*}{ Treatment of $P$. mufria } & \multirow{2}{*}{$\begin{array}{l}\text { P. mufria originally on: } \\
\text { Recovered from: }\end{array}$} & \multicolumn{2}{|c|}{ Apex } & \multicolumn{2}{|c|}{ Base } \\
\hline & & Apex & Base & Apex & Base \\
\hline \multicolumn{2}{|l|}{ Control 1: undisturbed } & 5 & 2 & 0 & 6 \\
\hline \multicolumn{2}{|l|}{ Control 2: removed and replaced } & 3 & 3 & 1 & 4 \\
\hline \multicolumn{2}{|l|}{ Removed and replaced on other end of host } & 5 & 3 & 3 & 5 \\
\hline \multicolumn{2}{|l|}{ Fisher's exact test } & \multicolumn{2}{|c|}{$P=0.26$} & \multicolumn{2}{|c|}{$P=0.99$} \\
\hline Total & & 13 & 8 & 4 & 15 \\
\hline$\chi^{2}=6.81 ; P<0.01$ & & & & & \\
\hline
\end{tabular}


Table 4. Experimental inversion of shells of Austrocochlea constricta. Data are numbers of limpets recovered after $24 \mathrm{~h}$ on the shore (out of 10 in each treatment); Fisher's exact tests according to the methods of Ghent (1972)

\begin{tabular}{|c|c|c|c|c|c|}
\hline \multirow[b]{2}{*}{ Treatment of $P$. mufria } & \multicolumn{5}{|c|}{ Treatment of Austrocochlea } \\
\hline & $\begin{array}{l}\text { Recovered } \\
\text { from }\end{array}$ & $\begin{array}{c}\text { Control } 1 \\
\text { Mobile with } \\
\text { glue on apex }\end{array}$ & $\begin{array}{l}\text { Control } 2 \\
\text { Mobile with } \\
\text { glue on base }\end{array}$ & $\begin{array}{l}\text { Control } 3 \\
\text { Glued with } \\
\text { base down }\end{array}$ & $\begin{array}{l}\text { Inverted } \\
\text { Glued with } \\
\text { apex down }\end{array}$ \\
\hline Control 1: & Apex & 1 & 0 & 0 & 6 \\
\hline Undisturbed & Base & 6 & 5 & 6 & 2 \\
\hline Control 2: & Apex & 1 & 0 & 0 & 5 \\
\hline Removed and replaced & Base & 7 & 8 & 3 & 1 \\
\hline Removed and replaced on & Apex & 1 & 0 & 0 & 3 \\
\hline other end of host's shell & Base & 2 & 4 & 5 & 0 \\
\hline \multicolumn{2}{|l|}{ Fisher's exact test: } & $P=0.65$ & $P=1.00$ & $P=1.00$ & $P=0.25$ \\
\hline \multirow[t]{2}{*}{ Total } & Apex & 3 & 0 & 0 & 14 \\
\hline & Base & 15 & 17 & 14 & 3 \\
\hline \multicolumn{6}{|c|}{$\begin{array}{l}\text { Fisher's exact test: Austrocochlea controls } 1,2 \text { and } 3: P=0.79 \\
\text { Fisher's exact test: Austrocochlea inverted versus controls: } P=10^{-8}\end{array}$} \\
\hline
\end{tabular}

hermit crabs of various species; these moved around at speeds similar to $A$. constricta, but may have influenced the limpets in various ways.

Fluorescence microscopy demonstrated that the osmotic treatments intended to reduce the amount of algae on the shells were extremely effective in reducing the amount of chlorophyll present to almost zero. However, it is not certain that these treatments also removed the damaged algal cells from the shells.

Patelloida mufria showed no preferences for empty shells or living, mobile or immobilized Austrocochlea constricta with different amounts of live epizoic algae on their shells. In one experiment $P$. mufria were given the choice of empty shells, hosts that had been scrubbed with sulphuric acid, and unscrubbed hosts. Unscrubbed snails were preferred to scrubbed snails which were preferred to empty shells, whether hosts were free to move or immobilized (Fig. 4). This may be an artefact due to chemical residues from the acid. Two experiments were done in attempts to alter the amount of microflora on shells of $A$. constricta without causing chemical artefacts. First, snails were kept in laboratory aquaria in continuous light, continuous darkness or a normal day/night cycle for $4 \mathrm{~d}$. It was hoped that these treatments would enhance and reduce, respectively, the abundance of microflora with respect to the third group. After $4 \mathrm{~d}, 15 \mathrm{P}$. mufria were placed on the bottom of a container with 5 hosts from each light regime. This combination of hosts and limpets was replicated in 3 such containers. The experiment was repeated with live, mobile and immobilized hosts and empty shells from recently killed hosts. There was no significant difference in the numbers of limpets climbing onto hosts that had been kept under different light

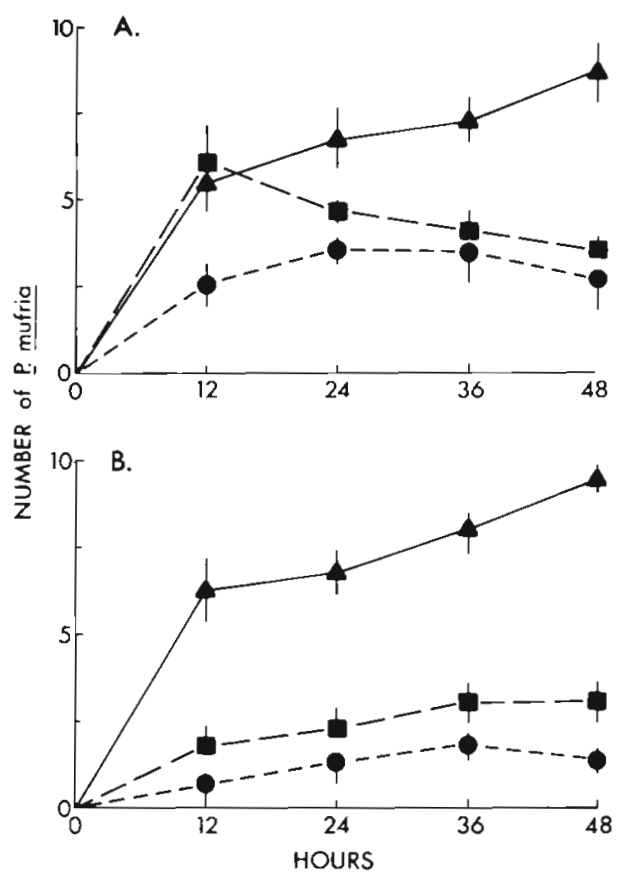

Fig. 4. Patelloida mufria. Mean ( \pm S. E.) number climbing onto Austrocochlea constricta in the laboratory ( $n=3$ replicate groups, each of 15 limpets). (A) Hosts were mobile (emptied shells contained hermit crabs); (B) immobilized hosts (secured by plasticene). $\Delta$ untreated live hosts; $\bullet$ untreated empty shells; $\mathbf{a}$ treated, live hosts (shells were scrubbed with sulphuric acid)

regimes, regardless of their mobility or whether the host was alive (Table 5A). It is, however, possible that these experimental treatments of the hosts made no difference to the microflora on their shells.

In another experiment, therefore, host shells were 
Table 5. Patelloida mufria. Numbers recovered after $48 \mathrm{~h}$ in the laboratory from shells of Austrocochlea constricta with natural, enhanced or reduced amounts of epizoic algae; replicates were pooled after preliminary chi-squared tests revealed no heterogeneity among containers

(A) Host snails kept under different light regimes: Numbers of limpets on hosts after $48 \mathrm{~h}$ (pooled from 3 replicate containers with each type of host)

$$
\text { Light regime }
$$$$
\text { Type of host available }
$$$$
\begin{array}{cc}
\text { Hosts alive Empty } \\
\text { Mo- Immo- } & \text { shells }
\end{array}
$$$$
\text { bile bilized }
$$

Light regime prior to experiment

Day/Night (control)

Kept in light (enhanced algae)

Kept in dark (reduced algae)

$$
\begin{aligned}
& \chi^{2}, 2 \text { df } \\
& \text { Probability }
\end{aligned}
$$

$\begin{array}{ccc}13 & 12 & 17 \\ 15 & 14 & 13 \\ 13 & 14 & 8 \\ 0.2 & 0.2 & 3.2 \\ >0.5 & >0.5 & >0.05\end{array}$

(B) Host snails dipped in solutions of various salinities: Numbers of limpets on hosts after $24 \mathrm{~h}$ (pooled from 2 replicate containers)

$$
\text { Treatment of host shells }
$$

No. of limpets

$$
\begin{aligned}
& \text { Osmotic stress (reduced algae) } \\
& \text { Controls } \\
& \qquad \chi^{2}, 1 \mathrm{df}=0.13, P>0.05
\end{aligned}
$$

treated with solutions of various osmolarities (see 'Methods') to remove microalgal cells. Sixteen Patelloida mufria were placed on the bottom of each of two laboratory containers with 16 undisturbed and 16 treated Austrocochlea constricta. There was again no effect of experimental removal of microflora on the selection of hosts by the limpets (Table 5B).

In a final series of experiments, Patelloida mufria were given the choice of Austrocochlea constricta that had been exposed to different previous intensities of grazing by the limpets, but were otherwise untreated. $A$. constricta collected from areas from which $P$. mufria were absent were presumed to have been subject to no recent grazing by the limpets. Snails without limpets on their shells but collected from nearby areas where P. mufria were abundant, may have been recently grazed but were not being grazed when collected. Other $\boldsymbol{A}$. constricta, from the same area, which had 2 limpets or 1 very large limpet on their shells were likely to have recently been subject to intensive grazing, whilst a fourth group of snails, carrying only 1 small limpet, were in a condition of less intense recent grazing. Following collection, all limpets were removed from their hosts and the hosts were marked according to their previous contact with $P$. mufria. Mixed populations of $15 \mathrm{~A}$. constricta from each of these 4 groups of snails were then placed in 2 replicate plastic trays, each with $50 \mathrm{P}$. mufria on the substratum. After $24 \mathrm{~h}, P$. mufria were found significantly more
Table 6. Patelloida mufria. Numbers recovered after $24 \mathrm{~h}$ in the laboratory from groups of Austrocochlea constricta having different prior contact with limpets; replicates were pooled after preliminary chi-squared tests revealed no heterogeneity between trays

(A) Experiment 1:50 P. mufria were released on the bottom of each of 2 replicates trays with 15 snails of each type (none of these snails had limpets on them)

Previous history of Austrocochlea

No. P. mufria (sum of 2 replicates)

With 1 large or 2 small limpets 4 (= much previous grazing)

With 1 small limpet

(= little previous grazing)

With no limpet

(= no immediately previous grazing)

With no limpet; no limpets in the area (= never previously grazed)

$$
\chi^{2}, 3 \mathrm{df}=27.5 ; P<0.001
$$

(B) Experiment 2: 26 Austrocochlea each with $1 P$. mufria were placed in each of 2 trays with groups of 15 snails of each type (none of these snails had limpets on them)

Previous history of Austrocochlea

No. P. mufria (sum of 2 replicates)

With 1 large or 2 small limpets 2 $1=$ much previous grazing

With 1 small limpet

(= little previous grazing)

With no limpet

(= no immediately previous grazing)

With no limpet; no limpets in the area (= never previously grazed)

$$
\chi^{2}, 3 \mathrm{df}=20.0 ; P<0.001
$$

abundantly on hosts in inverse proportion to the hosts recent experience of grazing (Table 6).

In a second, related experiment, the same groupings of Austrocochlea constricta were used, but the Patelloida mufria were on other $A$. constricta (1 limpet snail ${ }^{-1}$ ) instead of the substratum. Again, although relatively few limpets exchanged hosts, a significantly greater number moved onto $A$. constricta that were previously without any contact with the limpets than any other type of hosts (Table 6B).

\section{Consequences for Patelloida mufria of its association with Austrocochlea constricta}

\section{Desiccation and wave action}

Several experiments were done to assess the susceptibility of Patelloida mufria to desiccation and wave exposure, and the extent to which the effects of these physical variables were modified by the association of 
the limpets with Austrocochled constricta. In December 1977, replicate groups of 10 large $P$. mufria (6 to $7 \mathrm{~mm}$ shell length) were placed in cages at Jibbon Reef in 3 treatments: (1) P. mufria on emersed substratum, without access to pools and with no other gastropods present; (2) $P$. mufria on the substratum, submersed in pools; (3) $P$. mufria on $A$. constricta that had access to pools. $P$. mufria restricted to emersed substratum nearly all died during the first week of the experiment. Those in pools or on the shells of $A$. constricta suffered about 5 to $35 \%$ mortality during 3 weeks of observations (Fig. 5).

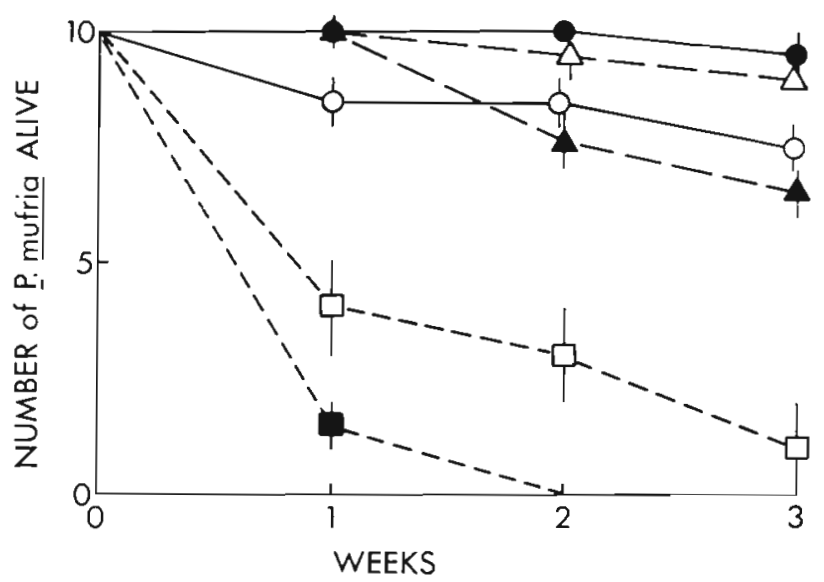

Fig. 5. Patelloida mufria. Mean ( $\pm \mathrm{S}$. E.) number surviving in pools $(\Delta, \Delta)$, on surfaces emersed during low tide $(\square, \square)$ and on shells of Austrocochlea constricta $(\bullet, 0)(n=2$ replicate groups, each of 10 limpets). Solid symbols: intertidal limpets; open symbols: sub-tidal limpets

Limpets living on the shells of other gastropods have shells with curved bases that fit the curvature of the host's shell. It is therefore unusual for such limpets to remain on bare rock even if they leave their hosts. The experiment was thus repeated using limpets collected from flat sub-tidal rocks; these have flat bases to their shells. Survival of these sub-tidal limpets when restricted to emersed rock was slightly better than that of the intertidal limpets in the former experiment, but was similarly reduced compared with survival of limpets in the other 2 treatments (Fig. 5). For both types of limpets, mortality was significantly greater when on emersed rock than when in a pool or on an Austrocochlea constricta, but did not differ between limpets in pools and those on a host (analysis of variance and SNK tests of means from the third week in Fig. 5; $P<0.05$ ).

During spring 1982, a series of similar experiments was done at Cape Banks and Fairy Bower, but without caging the gastropods (thus avoiding artefacts associated with cages). In the first of several such experiments, replicate groups of 15 Patelloida mufria
(>5 $\mathrm{mm}$ ) were marked and released on the substratum and on empty Austrocochlea constricta shells glued to the rock in emersed areas exposed to direct sun; emersed, shaded areas (although these received direct sunlight during the late afternoon); shallow pools ( $<10 \mathrm{~cm}$ deep); and deep pools ( $>50 \mathrm{~cm}$ deep). Limpets in deep pools would not be subject to any force from waves during high tide, whereas those in shallow pools or on emersed surfaces might be affected by waves. The results were even more dramatic than previously; there was considerable mortality of limpets during only $3 \mathrm{~d}$ (Fig. 6). On each of the $3 \mathrm{~d}$, surviving

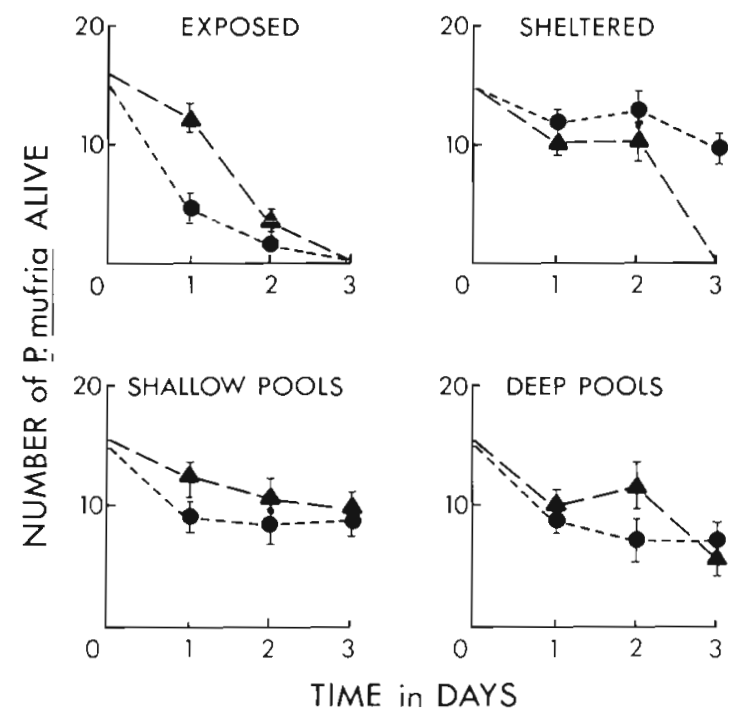

Fig. 6. Patelloida mufria. Mean ( \pm S. E.) number of live individuals recovered after being released onto rock (•) or immobilized shells of Austrocochlea constricta (4) in different microhabitats on the shore $(n=2-4$ replicate groups, each of 15 limpets)

limpets were found only in pools or in moist, sheltered locations. This included limpets that had originally been released on the substratum in exposed situations; those surviving had moved into small pools. By the end of the third day, there was very great mortality of limpets on glued-down shells of $A$. constricta in emersed, sheltered areas. This was apparently the result of the limpets being unable to leave these shells because no alternative hosts were available. Consequently, they were exposed to wind and direct insolation during low tide in the late afternoon. Mortality of $P$. mufria in deep pools was the result of predation. During the $3 \mathrm{~d}$ of the experiment, 9 limpets were seen being eaten by Morula marginalba; another 15 empty shells of limpets were found in the bottoms of deep pools. No limpets missing from deep pools were found elsewhere. The small number of limpets dying in shallow pools suggested that strong wave surge was not responsible for loss (by dislodgement) of limpets in either of the emersed locations. 
Several similar experiments were done during single periods of low tide. Replicate groups of 10 juvenile and 10 adult Patelloida mufria were placed on the substratum, or on the shells of free-moving Austrocochlea constricta in selected positions on the shore. These included limpets on rock exposed to direct sunlight, on emersed, shaded rock and in shallow pools. In addition, some areas of emersed, exposed rock were sprinkled with sea-water every 10 min during low tide. Sub-tidal limpets were exposed to the same environmental conditions, but without $A$. constricta. To control for the possible effects of removing the limpets from their hosts, groups of intertidal $P$. mufria and their hosts were placed on emersed, exposed rock and in shallow pools after the limpets had been removed from, and replaced on, their original hosts, or had been removed from their original hosts and placed on new snails. The experiments were done on sunny, windless days with ambient temperatures of about $27^{\circ} \mathrm{C}$.

Similar results to those described above were obtained, but in only $3.5 \mathrm{~h}$ (Table 7 ). For juvenile lim- small limpets on the shells of $A$. constricta survived. No $P$. mufria died in shallow pools. Results for subtidal limpets were similar to those for the intertidal limpets, except that survival of large sub-tidal individuals in exposed areas was slightly greater than that of intertidal limpets (Table 7A). These results were not caused simply by the experimental disturbance of limpets (Table 7B).

\section{Predation}

The muricid whelk Morula marginalba, a major predator on shores in New South Wales (Moran, 1980; Fairweather and Underwood, 1983; Fairweather et al., 1984), was seen eating limpets during the previous experiments. Accordingly, experiments were done to determine whether being on a host snail reduced the probability of $P$. mufria being eaten by a whelk. At Cape Banks, replicate groups of 15 adult $P$. mufria were caged in shallow pools with or without $A$. constricta and/or whelks (Table 8 ). Adult $(>5 \mathrm{~mm}$ ) and juvenile $(<5 \mathrm{~mm})$ limpets were examined separately

Tabie 7. Patelloida Inufria. Mean no. ( \pm S.E.) surviving for $3.5 \mathrm{~h}$ under different conditions of emersion during a single low tide $(n$ $=2$ replicate groups each of $10 \mathrm{P}$. mufria and, where appropriate, 10 Austrocochlea)

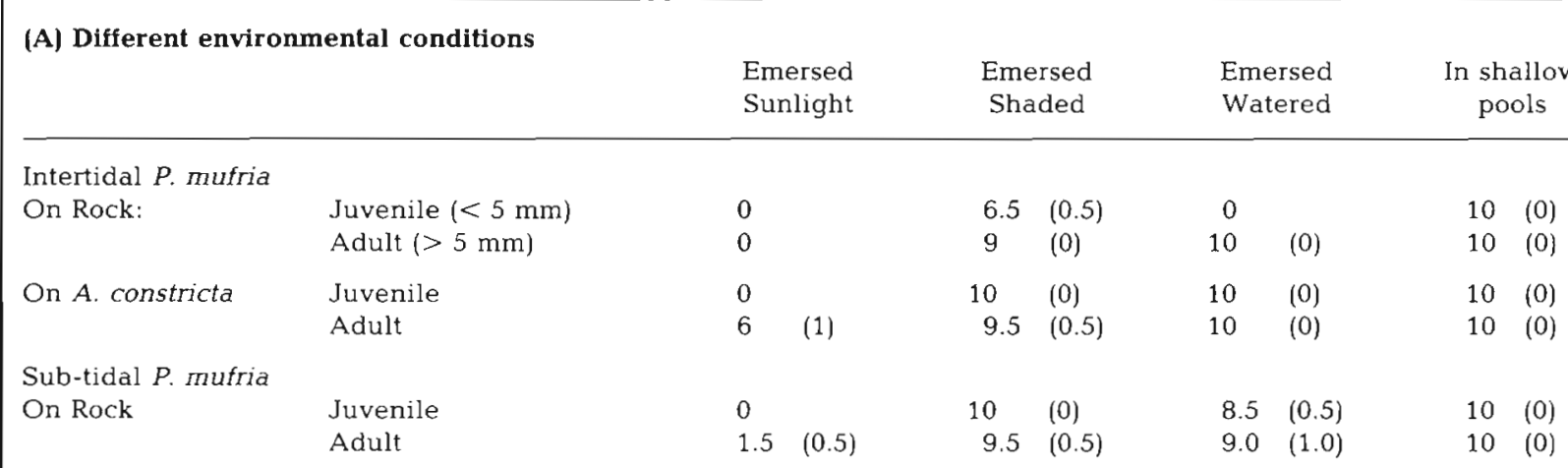

(B) Controls for experimental disturbance of the limpets (randomly chosen intertidal limpets of mixed sizes)

Removed and replaced on original host Removed and replaced on a new host
Emersed, direct sunlight

$$
0.5(0.5)
$$

$1.0 \quad(1.0)$
Shallow pools

$10 \quad(0)$ pets, the consequence of emersion and exposure to insolation during low tide was almost certain death, even if they were on the shells of Austrocochlea constricta. Mortality of adult Patelloida mufria was less on the shells of $A$. constricta. When $P$. mufria in emersed, exposed areas were kept moist by frequent sprinkling with seawater, mortality of adults and of those juveniles on $A$. constricta was reduced to zero. In contrast, juvenile limpets on the substratum all died even when sprinkled with water. Even in sheltered areas emersed during low tide, some $30 \%$ of juvenile limpets on the rock died, whilst all adults and those for some treatments. The experiment was also repeated in the laboratory using randomly chosen limpets (i.e. no distinction was made between juveniles and adults).

Morula marginalba was not a major predator of juvenile Patelloida mufria. The number of juvenile limpets recovered from each cage was much greater when there were Austrocochlea constricta in the cage, irrespective of the presence or absence of $M$. marginalba (analysis of variance of means in Table 8 ; $P<0.05$ ). Because of their small size, these juvenile $P$. mufria could not be reliably contained inside the 
Table 8. Patelloida mufria. Mean no. ( \pm S.E.) surviving for 1 wk with and without Morula marginalba in field and laboratory experiments ( $n=3$ replicates each of $15 \mathrm{P}$. mufria in each treatment); where appropriate, treatments contained $10 \mathrm{~A}$. constricta and/or 5 M. marginalba

\begin{tabular}{|c|c|c|c|c|c|c|}
\hline \multicolumn{2}{|c|}{ Experimental treatments } & \multicolumn{3}{|c|}{ Field experiments } & \multirow{2}{*}{\multicolumn{2}{|c|}{$\begin{array}{c}\text { In the laboratory } \\
\text { Mixed sizes }\end{array}$}} \\
\hline A. constricta & M. marginalba & $\begin{array}{l}\text { Juvenile } \\
(<5 \mathrm{~mm})\end{array}$ & \multicolumn{2}{|c|}{$\begin{array}{c}\text { Adult } \\
(>5 \mathrm{~mm})\end{array}$} & & \\
\hline Alive & Present & $13.7 \quad(0.3)$ & 14.5 & $(0.5)$ & 14.0 & $(0.6)$ \\
\hline Alive & Absent & $10.3 \quad(0.9)$ & 15.0 & $(0)$ & 15.0 & (0) \\
\hline Empty shell & Present & \multirow{2}{*}{$\begin{array}{l}\text { no data } \\
\text { no data }\end{array}$} & 6.0 & $(0)$ & 11.7 & $(0.2)$ \\
\hline Empty shell & Absent & & 12.5 & $(0.5)$ & 15.0 & (0) \\
\hline Absent & Present & $5.3 \quad(1.2)$ & 7.5 & $(1.5)$ & 8.3 & $(1.4)$ \\
\hline Absent & Absent & $4.3 \quad(2.3)$ & 7.5 & $(0.5)$ & 15.0 & $(0)$ \\
\hline
\end{tabular}

cages. It is therefore probable that losses of juvenile limpets simply reflected emigration of juveniles from cages where there were no potential hosts.

Where adult Patelloida mufria were on the rock, or on the shells of mobile Austrocochlea constricta, their mortality or loss from cages was not significantly affected by the presence of whelks (Table 8), but fewer limpets were recovered in cages where there were no A. constricta. Where limpets were caged on empty A. constricta shells mortality was, however, significantly greater in the presence of Morula marginalba than in their absence (analysis of variance of means in Table 8 ; $P<0.01$ ). The presence, or mobility, of live A. constricta reduced the intensity of predation by $M$. marginalba. It is not, however, clear why the mortality of $P$. mufria on the rock, without hosts, was not affected by $M$. marginalba. Some of the limpets placed on the substratum escaped from the cages, probably in search of suitable hosts; 4 such escapees were found at the end of the experiment.

When this experiment was repeated in the laboratory, where the limpets could not escape, the mortality of Patelloida mufria was significantly greater when whelks were present, when the limpets were on the substratum, or were on empty shells, than in similar treatments without whelks. In contrast, limpets on the shells of live, active Austrocochlea constricta were not susceptible to predation by the whelks (Table 8 ). No limpets died in any treatment where Morula marginalba were absent.

\section{DISCUSSION}

The association between Patelloida mufria and Austrocochlea constricta has been established from observations over the past $9 \mathrm{yr}$. This association is remarkable not only because it represents an uncommon phenomenon on intertidal shores, but also because the benefits of the relation for $P$. mufria are largely a product of the behaviour of its principal host, A. constricta. In few other relations between free-living intertidal animals and other organisms has it been demonstrated that the behaviour of a host plays a major role in the amelioration of the environmental stress suffered by the primary species.

For those species of Acmaea which inhabit only laminarian algae, the assumed reduction of competition and predation apparently results only from the life-history of the limpets and is not a function of the life-history of the kelps (A. R. Test, 1945; Graham and Fretter 1947; Black 1974, 1976; Branch 1975b, 1976; Choat and Black, 1979). The suggested reduction of susceptibility to desiccation and predation for light colour morphs of $A$. digitalis living on Pollicipes polymerus (Giesel 1970), if real, is a result of the behaviour of A. digitalis; it is not a product of behavioural responses of the sessile $P$. polymerus. The improved survival of juvenile $P$. cochlear on the shells of adult $P$. cochlear (Branch, 1975a, b, 1976) is perhaps a similar situation to that of Patelloida mufria on Austrocochlea constricta, but the former is an association between individuals of the same species. Two other heterospecific associations between two gastropods have been described previously (F. H. Test, 1945; Morton, 1980), but it is not known whether they have ecological causes or consequences similar to those demonstrated for $P$. mufria because little or no experimental work has been done to determine the nature of the association.

\section{Intrinsic factors: settlement and selection of hosts}

The restricted pattern of distribution of Patelloida mufria is already established by the time the limpets reach a visible size $(0.5$ to $1.0 \mathrm{~mm})$. If a requirement of residence in pools during low tide were the major factor delimiting the distribution of intertidal $P$. mufria then the limpets should also be found living on the 
substratum in large permanent pools. The abundance of $P$. mufria on the substratum below low tide indicates that the limpets can survive on rock, at least subtidally. If settlement were random and desiccation was the major cause of post-settlement mortality, then $P$. mufria in pools would be expected to occur on the shells of different gastropods in proportion to the surface areas of their shells. The absence of newly recruited $P$. mufria from Cellana tramoserica and Bembicium nanum might be explained as a consequence of the preference by these species for emersed areas during low tide in the areas studied. Thus, only those juvenile $P$. mufria that settled in pools or on gastropods that favour pools have a great probability of avoiding desiccation, and thereby surviving. This explanation for the observed distribution of juvenile $P$. mufria requires very great to complete mortality very soon after settlement of those individuals that do not settle in pools, or do not climb onto a shell within a pool. The causes of such major mortality are unclear, but the rates of death during single periods of low tide of limpets out of pools (Table 7) suggest that desiccation or other factors associated with emersion are involved. It is not, however, clear why small individuals of $P$. mufria should be so subject to rapid mortality when tiny individuals of Patelloida latistrigata settle and survive on open rock-surfaces (Creese, 1982; Underwood et al., 1983). Differential survival of limpets on different substrata cannot easily explain the absence of $P$. mufria from the shells of Nerita atramentosa or from the substratum in permanent pools. A strong preference by larval $P$. mufria for settlement on Austrocochlea constricta and, to a lesser extent, Subninella undulata and Morula marginalba, is possible but not consistent with the settlement of $P$. mufria in very large numbers on subtidal rocks (Fletcher, pers. comm.).

We have shown that intertidal Patelloida mufria of all visible sizes actively select Austrocochlea constricta in preference to other available gastropods (though subtidal limpets do not move onto the shells of other gastropods if placed intertidally). The mechanism involved in this selection is, however, not known. The preference by $P$. mufria for living, mobile snails compared with immobilized snails or empty shells suggests that the activity of a live host is important. This would be consistent with selection of hosts through chemodetection and/or tactile detection.

We have also shown that Patelloida mufria of all sizes frequently changed hosts. The selection of a new host almost certainly involves active choice among species (i.e. a preference for Austrocochlea constricta) but is apparently also related to the amount of food on the potential future host, its recent history with respect to grazing by other $P$. mufria, and its position with respect to pools. Selection of a host that has experi- enced little or no recent grazing is likely to enhance the amount of food available to the limpet on its new host. The mechanism by which $P$. mufria distinguishes between recently grazed and ungrazed hosts is not known. Recently grazed hosts are likely to be carrying fewer epizoic algae than ungrazed snails, but it is possible that they also carry chemical residues from the previous grazer. Negative responses by a limpet to either of these would cause the same pattern of selection of hosts by $P$. mufria. In experiments where epizoic algae were experimentally removed from $A$. constricta (i.e. snails with different crops of epizoic algae did not correspond to snails with different grazing histories), $P$. mufria generally showed no preferences consistent with the potential availability of food on host shells. This result suggests that the recent presence of another limpet on an $A$. constricta may deter a limpet from moving on to that snail. Multiple occupancy of hosts is, however, not consistent with this hypothesis, but it was rare to find more than one adult limpet on a single host.

The preference by Patelloida mufria for Austrocochlea constricta in, or moving into, pools over those that were moving out of pools is consistent with the implications of the great sensitivity of $P$. mufria to desiccation. Such behaviour would reduce the chance of a limpet being emersed during low tide. Positive geotaxis by $P$. mufria is also likely to reduce temperature stress for those limpets that do get caught out of water at low tide. For all but the largest $P$. mufria, being at the base of an $A$. constricta will mean being under the overhanging lip of the host's shell and hence protected from desiccating processes in much the same way as Eikenberry and Wickizer (1964) suggested for Acmaea asmi on Tegula funebralis. During low tide, many $A$. constricta trap water in the mantle cavity, and in and under the body-whorl of the shell.

\section{Extrinsic factors: desiccation and predation}

Underwood (1979) emphasized the difficulty involved in demonstrating that desiccation is a cause of natural mortality of animals. Several authors have pointed out that mobile organisms rarely encounter conditions in nature that exceed their physiological tolerance to high temperature or reduced humidity for long enough to cause death through desiccation (Southward, 1958; Wallace, 1972; Wolcott, 1973; Underwood, 1979). Hodgkin (1959) reported catastrophic mortality of intertidal animals during summer on a Western Australian shore and he attributed these deaths to unusually high temperatures. Frank (1965) argued that desiccation was a major cause of mortality of Acmaea digitalis during summer. Wolcott (1973) suggested that desiccation was occasionally respon- 
sible for great mortality of $A$. scabra and $A$. digitalis in high-shore areas when low tide occurred on hot, calm, sunny days. He hypothesized that only those species with a distribution extending to high shore areas would have their distribution delimited by physiological stress, particularly desiccation.

Much of the pattern of distribution of Patelloida mufria can probably be explained by the chances of being desiccated. Even in low mid-shore areas, $P$. mufria exposed at low tide on hot sunny days are likely to die, apparently as a result of heat stress and desiccation. Given that $P$. mufria is somehow prevented from living on the substratum intertidally, the association of P. mufria with Austrocochlea constricta clearly enhances the capacity of $P$. mufria to remain in pools or, if caught out of pools at low tide, to survive until the ensuing high tide. The fact that $P$. mufria dies within a very short period of exposure at only moderately high temperatures $\left(27^{\circ} \mathrm{C}\right)$ indicates a very low physiological tolerance of temperature stress which apparently severely limits the potential distribution of this limpet.

The alleviation of temperature stress for Patelloida mufria through association with Austrocochlea constricta does not, however, completely explain the observed intertidal distribution of $P$. mufria. The question remains: why are limpets unable to survive on the substratum in permanent pools? Our results indicate that $P$. mufria on immobilized shells or on the substratum in pools suffer far more from predation by the whelk Morula marginalba than limpets on mobile $A$. constricta. The inconclusive results from the field treatments in which $P$. mufria were caged alone or with only $M$. marginalba, need not be considered to reach this conclusion. Data from other caged treatments and from desiccation experiments indicated that, in the absence of alternative hosts, $P$. mufria tend to remain on host shells rather than move onto the substratum. This suggests that in the treatments where $P$. mufria were caged on immobilized shells with $M$. marginalba, the loss of limpets was probably the result of predation rather than emigration. This conclusion was supported by the results of the laboratory experiment on predation.

The exact mechanism by which Patelloida mufria on Austrocochlea constricta are able to avoid the predatory whelk Morula marginalba is not clear. Bullock (1953) documented several escape responses of gastropods confronted by predatory starfish. There is, however, little evidence of avoidance or escape behaviour by $A$. constricta in response to $M$. marginalba (Underwood, unpubl.; Fairweather, pers. comm.). Yet, few $A$. constricta are naturally eaten by $M$. marginalba, even when the whelk has been starved for extended periods (see also Fairweather et al., 1984).

Morula marginalba were relatively uncommon at some of our study sites. It thus seems unlikely that these whelks could have been responsible for eliminating all post-larval Patelloida mufria that settled on rock in pools before they recruited to a visible size. The presence of juvenile (but not adult) $P$. mufria on the shells of $M$. marginalba in the field suggests that juvenile limpets may be relatively immune from predation by $M$. marginalba. If confirmed, this immunity would further indicate that $M$. marginalba was not responsible for extreme mortality of newly-settled $P$. mufria in pools.

Intertidally, Patelloida mufria has an extremely limited distribution which is, at least partially, the result of its own behavioural specializations and partly the result of the influence of desiccation and predation. Subtidally, this limpet has a very general distribution and does not apparently demonstrate any of the specialized behaviour characteristic of intertidal individuals (Fletcher, pers, comm.). It is difficult to envisage a mechanism that could sustain such diverse behaviour by one species in different habitats. Further work on subtidal limpets, including experimental transplants between habitats, is needed before the two life-styles can be compared and interpreted, particularly to determine whether the two morphs are, in fact, the same species.

The interpretation of specialized modes of life in animals is often problematic. This is particularly so when portions of the animal's life-history (such as planktonic marine larvae) are invisible to us and beyond our control. Ecological specialization suggests specific behavioural strategies of individuals that substantially determine their distribution and abundance. Apparent specialization can, however, result from environmental factors acting to restrict the distribution and abundance of species that demonstrate generalist or opportunistic behaviour. Resolution of the relative importance of these intrinsic and extrinsic factors is thus imperative if the important distinction between specialization and generalist or opportunistic behaviour is to be made for any species.

Acknowledgements. This work was supported by funds from the Australian Research Grants Committee (to AJU) and the University of Sydney Research Grant (to AJU and RGC), and by Commonwealth Postgraduate Research Awards (to BDM and $\mathrm{RGC}$ ). We are grateful for discussions, advice and help from P. G. Fairweather, W. J. Fletcher, G. Mercer, A. Creese, Professor D. T. Anderson, Drs. J. H. Choat and P. A. Underwood, and to our colleagues and students in the Ross Street Laboratories. Some of the experimental data were kindly provided after undergraduate class exercises by $\mathrm{K}$. Bertazzo, G. Liggins, U. MacLulich, C. Phillips and D. Salt. 


\section{LITERATURE CITED}

Alleman, L. L. (1968). Factors affecting the attraction of Acmaea asmi to Tegula funebralis. Veliger 11 (Suppl.): $61-63$

Barnes, H. (1953). Orientation and aggregation in Balanus balanus (L) Da Costa. J. Anim. Ecol. 22: 227-241

Black, R. (1974). Some biological interactions affecting intertidal populations of the kelp Egregia laevigata. Mar. Biol. 28: $189-198$

Black, R. (1976). The effects of grazing by the limpet Acmaea insessa on the kelp Egregia laevigata in the intertidal zone. Ecology 57: 265-277

Black, R. (1979). Competition between intertidal limpets: an intrusive niche on a steep resource gradient. J. Anim. Ecol. 48: 401-412

Branch, G. M. (1975a). Intraspecific competition in Patella cochlear Born. J. Anim. Ecol. 44: 263-282

Branch, G. M. (1975b). Mechanisms reducing intraspecific competition in Patella spp.: migration, differentiation and territorial behaviour. J. Anim. Ecol. 44: 575-600

Branch, G. M. (1976). Interspecific competition experienced by South African Patella species. J. Anim. Ecol. 45: $507-530$

Bullock, T. H. (1953). Predator recognition and escape responses of some intertidal gastropods in presence of starfish. Behaviour 5: 130-140

Choat, J. H. (1977). The influence of sessile organisms on the population biology of three species of acmaeid limpets. $J$. exp. mar. Biol. Ecol. 26: 1-26

Choat, J. H., Black, R. (1979). Life-histories of limpets and the limpet-laminarian relationship. J. exp. mar. Biol. Ecol. 41 : $25-50$

Creese, R. G. (1978). Ecology and reproductive biology of intertidal limpets. Unpublished Ph. D. thesis, University of Sydney

Creese, R. G. (1980). An analysis of distribution and abundance of populations of the high-shore limpet Notoacmea petterdi (Tenison-Woods). Oecologia (Berl.) 45: 212-260

Creese, R. G. (1982). Distribution and abundance of the acmaeid limpet Patelloida latistrigata, and its interaction with barnacles. Oecologia (Berl.) 52: 85-96

Creese, R. G., Underwood, A. J. (1976). Observations on the biology of the trochid gastropod Austrocochlea constricta (Lamarck) (Prosobranchia). I. Factors affecting shell-banding. J. exp. mar. Biol. Ecol. 23: 211-228

Creese, R. G., Underwood, A. J. (1982). Analysis of inter- and intra-specific competition amongst limpets with different methods of feeding. Oecologia (Berl.) 53: 337-346

Crisp, D. J. (1974). Factors influencing the settlement of marine invertebrate larvae. In: Grant, P. T., Mackie, A. M. (ed.) Chemoreception in marine organisms. Academic Press, London, p. 177-267

Eikenberry, A. B., Wickizer, D. E. (1964). Studies on the commensal limpet Acmaea asmi in relation to its host, Tegula funebralis. Veliger 6 (Suppl.): 66-70

Fairweather, P. G., Underwood, A. J. (1983). The apparent diet of predators and biases due to different handling times of their prey. Oecologia (Berl.) 56: 169-179

Fairweather, P. G., Underwood, A. J., Moran, M. J. (1984). Preliminary investigations of predation by the whelk Morula marginalba. Mar. Ecol. Prog. Ser. 17, in press

Frank, P. W. (1964). On home range of limpets. Am. Nat. 98: 99-104

Frank, P. W. (1965). The biodemography of an intertidal snail population. Ecology 46: 831-844

Ghent, A. W. (1972). A method for exact testing of $2 \times 2,2 \times 3$
$3 \times 3$ and other contingency tables, employing binomial coefficients. Am. Midl. Nat. 88: 15-27

Giesel, J. T. (1970). On the maintenance of a shell pattern and behaviour polymorphism in Acmaea digitalis, a limpet Evolution 24: 98-119

Graham, A., Fretter, V. (1947). The life-history of Patina pellucida (L.). J. mar. biol. Ass. U. K. 26: 590-601

Hendler, G., Franz, D. R. (1971). Population dynamics and life history of Crepidula convexa Say (Gastropoda: Prosobranchia) in Delaware Bay. Biol. Bull. mar. biol. Lab., Woods Hole 141: 514-526

Hodgkin, E. P. (1959). Catastrophic destruction of the littoral fauna and flora near Fremantle, January, 1959. W. Aust. Nat. 7: 6-11

Knight-Jones, E. W. (1953). Laboratory experiments on gregariousness during settling in Balanus balanoides and other barnacles. J. exp. Biol. 30: 584-598

Mackay, D. A., Underwood, A. J. (1977). Experimental studies on homing in the intertidal patellid limpet Cellana tramoserica (Sowerby). Oecologia (Berl.) 30: 215-238

Meadows, P. S., Campbell, J. I. (1972). Habitat selection by aquatic invertebrates. Adv. mar. Biol. 10: 271-382

Moran, M. J. (1980). Ecology and effects on its prey of the intertidal predatory whelk Morula marginalba Blainville. Unpublished Ph. D. thesis, University of Sydney

Morton, B. S. (1980). Selective site segregation in Patelloida (Chiazacmea) pygmaea (Duncker) and P. (C.) lampanicola Habe (Gastropoda: Patellacea) on a Hong Kong shore. J. exp. mar. Biol. Ecol. 47: 149-171

Orton, J. H. (1950). The recent extension in the distribution of the American slipper limpet Crepidula fornicata into Lyme Bay in the English Channel. Proc. malac. Soc. Lond. 28: $168-184$

Ponder, W. F., Creese, R. G. (1980). A revision of the Australian species of Notoacmaea, Collisella and Patelloida (Mollusca: Gastropoda: Acmaeidae). J. malac. Soc. Aust. 4: $167-208$

Southward, A. J. (1958). Note on the temperature tolerances of some intertidal animals in relation to environmental temperatures and geographical distribution. J. mar. biol. Ass. U. K. 37: 49-66

Steneck, R. S. (1982). A limpet-coralline alga association: adaptations and defenses between a selective herbivore and its prey. Ecology 63: 507-522

Stimson, J. (1970). Territorial behaviour of the owl limpet Lottia gigantea. Ecology 51: 113-118

Stimson, J. (1973). The role of the territory in the ecology of the intertidal limpet Lottia gigantea (Gray). Ecology 54: $1020-1030$

Sutherland, J. P. (1970). Dynamics of high and low populations of the limpet Acmaea scabra (Gould). Ecol. Monogr. 40: $169-188$

Test, A. R. (1945). Ecology of Californian Acmaea. Ecology 26 395-405

Test, F. H. (1945). Substrate and movements of the marine gastropod, Acmaea asmi. Am. Midl. Nat. 33: 791-793

Thorson, G. (1965). A neotenous dwarf form of Capulus ungaricus (L.) (Gastropoda: Prosobranchia) commensalistic on Turitella communis Risso. Ophelia 2: 175-210

Underwood, A. J. (1976). Analysis of patterns of dispersion of intertidal prosobranch gastropods in relation to macroalgae and rock-pools. Oecologia (Berl.) 25: 145-154

Underwood, A. J. (1978). An experimental evaluation of competition between three species of intertidal gastropods. Oecologia (Berl.) 33: 185-208

Underwood, A. J. (1979). The ecology of intertidal gastropods. Adv. mar. Biol. 16: 111-210 
Underwood, A. J. (1981). Structure of a rocky intertidal community in New South Wales: patterns of vertical distribution and seasonal changes. J. exp. mar. Biol. Ecol. 51: $57-85$

Underwood, A. J., Denley, E. J., Moran, M. J. (1983). Experimental analyses of the structure and dynamics of midshore rocky intertidal communities in New South Wales. Oecologia (Berl.) 56: 202-219

Vahl, O. (1971). Growth and density of Patina pellucida (L.) (Gastropoda: Prosobranchia) on Laminaria hyperborea (Gunnerus) from Western Norway. Ophelia 9: 31-50
Wallace, L. R. (1972). Some factors affecting vertical distribution and resistance to desiccation in the limpet Acmaea testudinalis (Muller). Biol. Bull. mar, biol. Lab., Woods Hole 142: 186-193

Wolcott, T. G. (1973). Physiological ecology and intertidal zonation in limpets (Acmaea): a critical look at 'limiting factors' Biol. Bull. mar. biol. Lab., Woods Hole 145: $389-422$

Wyatt, H. V. (1960). Responses of larvae of Calyptraea chinensis (L.) to light. Nature, Lond. 186: 328

This paper was presented by Professor G. F. Humphrey; it was accepted for printing on January 30, 1984 